\title{
Development of Audio-Visual Learning Media for Islamic Religious Education in High School
}

\author{
Nurhayati ${ }^{1}$, Husain Syam ${ }^{2}$, Sulaiman Samad ${ }^{3}$ \\ ${ }^{1}$ Department of Educational Science, Universitas Negeri Makassar \\ Jln. Bonto Langkasa Kampus Gunung Sari Baru, Makassar, South Sulawesi, Indonesia \\ Email: nurhayati [AT] iaialmawar.ac.id \\ ${ }^{2}$ Department of Engineering, Universitas Negeri Makassar \\ Jln. Bonto Langkasa Kampus Gunung Sari Baru, Makassar, South Sulawesi, Indonesia \\ Email: husainsyam [AT] unm.ac.id \\ ${ }^{3}$ Department of Educational Science, Universitas Negeri Makassar \\ Jln. Bonto Langkasa Kampus Gunung Sari Baru, Makassar, South Sulawesi, Indonesia \\ Email: essamad [AT] unm.ac.id
}

\begin{abstract}
This study aims to: (1) Knowing the description of the needs of Islamic Religious Education learning media (2) Knowing the design of the media (3) Knowing the valid and practical learning media (4) Knowing the effective learning media. The development procedure is based on 4-D development, namely "define, design, develop, and disseminate". Results of the study 1) Need of Islamic education instructional media, necessary given the scope of material is very wide and time is very limited. 2) An overview of the design of learning media through stages; a) design, b) The design of the device c) Development Instrument Design d) learning media design 3) Media Learning is valid, the media validation has average of 4.7 is excellent. The average learning aspect is 4.6 very good. The average learning aspect is 4.8 in the very good category. While the practicality by looking at the activities of students and teachers the average value of 4 categories is carried out. 4) Overview of effectiveness a) Student activities by observing. In general, student activities are in the range of tolerance limits, $b$ ) the teacher's response obtained an average value of 4.57 (89\%) very good category.
\end{abstract}

Keywords--- Learning Media; Audio Visual; Islamic Religious Education

\section{INTRODUCTION}

One important factor in building the quality of education is the quality of educators in designing and implementing learning. Teachers should have adequate skills to design, develop and utilize learning media in an effort to increase students' interest, attention, and motivation to learn [1]. Acquisition of knowledge and skills, changes attitudes and behavior can occur because the interaction between a new experience and previous expriences with the experience. The teacher as a source of messages pours messages into certain symbols ( encoding ) and students as recipients interpret these symbols so that they are understood as messages ( decoding ) [2].

Technology has become an inseparable part of all aspects of human life. In almost all activities, humans use technology, both simple technology and advanced technology. Information technology can act as a learning medium that is designed and developed in order to convey the information and knowledge needed by the audience or students. Especially now, learning media is no longer only functioned as a mere message distributor ( content oriented), but more than that, namely as a source of learning to achieve learning goals ( learning resources).

The presence of the media has a fairly important meaning, because in learning activities, the ambiguity of the material presented can be helped by presenting the media as an intermediary. The development of science and technology increasingly encourages renewal efforts in the use of technological results in the learning process.

Audio visual media is a teaching aid to convey learning. Audio-visual media has an element of motion that is able to attract the attention and motivation of students in carrying out learning activities. Audio visual has the advantage of being able to help understand learning messages more meaningfully. With the motion and animation elements possessed by audio-visual, of course, it is expected to be able to attract the attention of students longer when compared to other learning media. The use of audio-visual learning media is important to develop so that the learning process involves two senses, namely the sense of sight and the sense of hearing. It is important that students focus on the learning material. 


\section{LITERATURE REVIEW}

\subsection{Learning}

Learning is an activity in which teachers perform the role - specific roles that learners can learn to achieve the expected educational goals. Teaching strategies are all methods and procedures that focus on the activities of students in the teaching and learning process to achieve certain goals [3].

Learning is a process of teaching students to be able to learn something that is relevant and meaningful to themselves, besides that, it is also to develop a learning experience where students can actively create what they already know with the experience gained. And this activity will result in students learning something more effectively and efficiently [4].

\subsection{Islamic Education}

Education has an important role in the development of a civilization, including Islamic civilization. In the context of Islam, the notion of education refers to the terms commonly used, namely, ta'lim, tarbiyah, and ta'dib. The term ta'lim with the verb 'allama implies telling or giving knowledge [5]. So, this term can be interpreted as teaching, as in Arabic the term tarbiyah wa ta'li $m$ is often used to mean education and teaching [6]. According to [7] the word 'allama gives the meaning of simply telling or giving knowledge, it does not mean personality development because there is very little possibility of personality formation caused by the provision of knowledge.

The term tarbiyah the dictionary Arabic comes from fi'il mad $i$ is robba and mud ari ' his yurobba, which means maintaining, care and educate. In the form of masdar it becomes tarbiyah, which means maintenance, bring up, and educate. (Munawwir, 2015: 426 ) . In the context of Islamic education, contemporary writers among Arab Muslims mostly use the term tarbiyah for the meaning of education [8].

The above understanding can be understood if the concept of tarbiyah is a process of educating humans with the aim of improving human life in a more perfect direction. It is not only seen as the process of educating, but also includes the process of managing and arranging so that the journey of smooth life.

[5] Provides a view that the general goal of Islamic education is to form perfect Muslims in the sense of faith and piety or humans who worship Allah. In addition, al-Gazali and Ali al-Jumbulati also revealed that the purpose of education is religious morals to get closer to Allah swt.

\subsection{Islamic Education Goals}

The purpose of Islamic education is an ideal condition of the object of learning to be achieved, namely all activities in the education system are directed. All ideas to formulate the goals of Islamic education must take into account that the arrival of Islam is a new beginning for humans. Islam came to improve the human condition, perfect the previous messengers of God, and in order to achieve the perfection of religion.

[9] summarizes the goals of Islamic education into two things. First, the formation of pious people. Pious people are humans who are close to perfection, namely the development of humans who worship and fear Allah swt. Second, the formation of a pious society. A pious society is a society that believes that it has a message for mankind, namely a treatise of justice, truth, and goodness. The treatise is a treatise that will last forever, regardless of time and place.

\subsection{Islamic Religious Learning Media}

Media is Latin Language and the plural form of the word " medium" which literally means "intermediary" which is an intermediary between the source of the message and the recipient of the message. According to Heinich in [10] media is a communication tool. There are media that can only be used by teachers ( by utilization) in learning activities, as well as natural media available in the school environment including those that can be used directly. In addition, we can also design and create our own media (by design) according to the abilities and needs of students . Media is a tool that can be completed properly and with satisfactory results. Media is a vehicle for distributing learning information and distributing messages. In one of the journals mentioned that the electronic media, especially television has long been criticized because of the potential impact on children. One sector that needs to be considered how are media exposure influence development of cognitive and academic achievement.

Modern society, with science and technology were progressing rapidly, has been seeing a rare increase exponentially in the knowledge that can be accessed and continue to change as technology development [11].

Technology has created changes for many professions, professional counseling being one of them. Like those of the publisher and industry computer makes the technology more friendly users and easily accessible, counselors have begun 
to embrace technology as a method of learning [12].

Learning media is used to facilitate the delivery of material to students. Students will be helped in understanding complex material. The use of media also plays a major role in providing students' learning experiences. Learning is an interaction between a person with other people, the media, or with the environment. Indications of effective, cognitive, psychomotor and physical changes are characteristics of students who have learned from what they have received [2] .

The learning process is a process of communication between teachers and participants of learners through verbal language as the main medium of delivery of material learning. In the conditions of a kind of this, the learning process is very dependent teachers as a source of learning. However,in reality not all learning materials canbe presented bythe teacher directly. To learn how the lives of creatures living at the bottom of the sea, there may be a teacher to guide participants learners directly dive kedasar ocean, or splitting the man's chest just to learn how the body organs of human. However, teachers can use various kinds of style $t$ help in conveying Oversight of the horse. Tools to help learn this is what the media or means of visual learning [13].

\subsection{Various Media in Islamic Religious Education Learning}

Media learning Islamic education is a container of the message delivered by the source or distributors educators, to target or recipient of the message, the participant students are learning [14]. The purpose of use of instructional media such that the learning process of Islamic religious education can take place with either. The learning media for Islamic religious education can be classified into two types, namely material media (objects) and non-material media (non-objects).

\section{a. Material Media}

Media material is the medium in the form of inanimate objects that can support the process of learning which is called also the visual media, such as space class, equipment to learn, and so forth. This media has a very broad scope, including :

\section{b. Audio Media}

Audio media is media or materials that contain messages in auditive form (vocal cords or vocal discs ) that can stimulate the thoughts and feelings of listeners so that the learning process occurs. The relationship between this audio media and the purpose of learning Islamic religious education is very close. From a cognitive perspective, this audio media can be used to teach various rules and principles. In terms of affective this audio media to create an atmosphere of learning and in terms of psychomotor, this audio media to teach media verba skilll. As an auditive media, this media is closely related to radio, magnetictape recording devices, vnyl record, or a language laboratory [14].

\section{c. Print Media}

Media print is the most widely and most frequently used. This media serves to distribute the message from the sender to the recipient of the message (from the teacher to the participant students). In simple terms, print media can be interpreted as media that contains messages that are poured in the form of writing, letters, pictures, and symbols that contain meaning.

Print media is the purpose of cognitive can function to convey information that is real. For the purpose affective print media is able to support a material in conjunction with a change in attitude and behavior. For psychomotor purposes, this print media can show the position of something that is happening and teach various steps and principles in the learning process [15]. Various kinds of print media include: pictures/photos, diagrams, charts, posters, graphs, books.

\section{d. Electronic Media}

This media is created to convey the information education that can be used in general, both in the educational and community are extensive. Some of the electronic media in question include: Slides and film strips, television, radio, computers [16].

\section{RESEARCH METHODS}

This research is the Research and Development $(\mathrm{R} \& \mathrm{D}) . \mathrm{R} \& \mathrm{D}$ research is used for the following reasons: (1) teachers have not maximized the use of learning media, so researchers will modify and develop Islamic Religious Education learning media as innovations, (2) the products produced from R\&D are expected to balance conventional learning.

$\mathrm{R} \& \mathrm{D}$ is defined as "a research method that is intentional, systematic, aimed/directed to find, formulate, improve 
models, methods/strategies/methods, certain procedural services that are superior, effective, efficient, productive, and meaningful. The model used in this study is a 4-D model (Four-D Model) developed by [17] includes the stages of defining ( Define ), design ( Design ), development ( Develop ) and dissemination (Disseminate).

This research is intended to develop and design learning media for Islamic Religious Education. The development procedure carried out in this study will refer to the 4- D development. The researcher chose this model because the 4- D model is a development model whose stages are in accordance with the development needs of the media to be studied.

This research was carried out in several steps. Each of these steps involves a different subject. The research subjects are the subject of needs analysis, the subject of content and construct analysis, and the subject of field testing.

\section{RESULTS AND DISCUSSION}

\subsection{An overview of the need for developing audio-visual media for Islamic learning in senior high schools}

The learning process is a process of communication between teachers and students through verbal language as the main medium for delivering learning materials. In these conditions, the learning process is very dependent on the teacher as a learning resource. However, in reality not all lesson materials can be presented by the teacher directly. To learn how the life of living things on the seabed, it is impossible for teachers to guide students directly to the bottom of the ocean, or split open the human chest just to learn how the human organs work. However, teachers can use various tools in delivering teaching.

As well Islamic Religious Education, in teaching the reading of the Qur'an not all Islamic Education teachers have a melodious voice to set an example for students. So to make it easier for Islamic Education teachers, they can be assisted by using audio media. There are many materials in Islamic Education Teacher learning that really need learning media so that learning objectives can be achieved, especially considering that face-to-face time is only $3 \mathrm{X} 45$ minutes every week while the material is very broad.

This is in line with the researchers' observations that Islamic Religious education teachers only occasionally use learning media, in the researcher's observations the classroom atmosphere is very different whenIslamic Religious education teachers use learning media with when they do not use learning media. When Islamic Religious education teachers use learning media, the class atmosphere seems lively, the faces of students look motivated and enthusiastic about participating in learning. In contrast to the learning atmosphere when not using the media, the classroom atmosphere seems sluggish, lacks enthusiasm, and students take turns leaving for permission for various reasons.

Researchers also pay attention to the design or learning media products that are still very simple, only visually using power point applications. The teacher has not included audio into the learning media used.

Researchers also conducted interviews with students, students basically in following the learning process are very dependent on the teacher, if the teacher in teaching using the media is certainly enthusiastic, motivated and focused, because if in the explanation of the material the teacher only watches using the lecture method, the students are more easily sleepy and lost concentration.

\subsection{Overview of Islamic Religious Learning Media Design in High Schools}

At this design stage, discussed. 1) Design of Islamic Religious Education learning, 2) learning device design, 3) Validation Test, and 4) Test Result

\section{a. Design of Islamic Religious Education learning}

The design of Islamic religious education learning in question is a learning process carried out using the results of the development of Islamic religious education learning media starting from the preparation stage of learning, implementation of learning to evaluation. Therefore, matters relating to the process of implementing learning need to be prepared in such a way that Islamic religious education learning goes well, practically, and efficiently.

Another thing to consider is the learning environment. Before learning begins, the teacher must ensure that all supporting equipment used in the learning process is in good condition and ready to use, in order to create a conducive learning environment. Teachers need to place laptops (computers) and LCD in such a way that the learning process goes well. As a class management controller, the teacher needs to adjust the student's sitting position, regulate and direct how students are actively involved, speak and express their thoughts. Guiding students to work on worksheets and carry out evaluations.

The next learning scenario, namely the steps or activities carried out during the learning process. Basically, the learning scenario is contained in the lesson plans. The learning scenario are divided into 3 activities, namely initial activities, core activities, and closing activities. 


\section{b. Learning Device Design}

The design of Islamic Religious Education Learning media devices intended here is to complete learning tools that are not complete or do not yet exist and include them in learning media that are developed as supplements. The learning tools include lesson plans (RPP), teaching materials, worksheets, learning media, and evaluations. The discussion on the development of learning media is limited with the consideration that in developing learning media, other learning devices are indirectly involved.

Lesson Plan learning tools. The lesson plans are prepared referring to the curriculum used in SMA Negeri 1 Kolaka, namely the 2013 curriculum. The next learning device is teaching materials. Teaching materials is also taken from reference books used in SMA Negeri 1 Kolaka.

The student activity sheet (LKS) is the next learning tool. LKS are sheets containing assignments that must be done by students in a certain time. The advantage of using LKS for teachers is that it makes it easier for teachers to carry out learning, while for students, they will study independently, learn to understand, and carry out a written assignment. The LKS used by the teacher is not complete, nor is the format of the composition, therefore, in the development of this learning media, the LKS is completed and for more details, can be seen in the appendix.

Learning media is very important in the learning process, but this device is also prepared on the media. Learning media prepared using Macromedia Flash 8 application program.

Evaluation is a process of describing students and weighing them in terms of value and meaning. The evaluation is prepared referring to the learning objectives to be achieved. In the early learning activities, a pretest was conducted to see how far the students understood the material to be taught. At the end of the core activity, a post-test was conducted to determine the extent to which students had understood the teaching material that had been taught or how the learning objectives were achieved. KKM (Minimum Completeness Criteria) is a reference or basic guideline in determining the achievement of student learning outcomes or the lowest criteria for declaring students to achieve mastery learning.

\section{c. Validation Test}

The validation test is intended to see how far the learning media developed is feasible to use. The validation test for this learning media is a media and material expert. Based on the test results, where the results of the validation of media and material experts, both the display aspect and the learning aspect are in the very good category. As well as, when viewed from the validator's assessment, the assessments given are almost no different. This means that the learning media developed is valid, although there are slight improvements and these improvements have been made. For the learning materials used there are also suggestions for improvement, and these suggestions have been refined so that in terms of the material on this learning media it is feasible to use.

The improvement in question is advice from media experts, what is recommended is an image background with the type of writing. Between the background of the image and the text so that there is no contrast, so it is easy to see. This suggestion has been corrected.

\section{d. Test results}

As previously stated, the trial was carried out in class XI at SMA Negeri 1 Kolaka. The test results include teacher and student activities as well as student learning outcomes. Based on these results, it can be explained in more detail as follows:

\section{Student and teacher activities}

The activities of students and teachers basically refer to the lesson plans, but there are some additional activities that are adapted to the conditions of the class when the learning takes place. The activities of students and teachers are interconnected or in pairs, the teacher instructs and students carry out the teacher's instructions. The observed student activity is the extent to which students actively participate in learning from time to time, while in teacher activity, what is observed is the extent to which teacher activities follow the learning steps listed in the lesson plans.

Based on the results of observations as stated in the previous section, it can be seen that in the trial, generally students are active, then the aspects of learning carried out by the teacher are the methods and learning media used by the teacher. When associated with students, students' views of learning media are in the good category, so that the influence of using learning media is dominant.

For teacher activities, generally they have followed the learning steps as stated in the lesson plans. In the initial activity, the teacher carried out student attendance to check student attendance. But what is often forgotten is conveying the learning objectives. The teacher immediately conveys the material to be studied. In core activities, teachers generally master the subject matter, approaches and strategies. The use of learning tools by students is indeed not optimal, because the media used is limited, adapted to school conditions. In the final activity, the involvement of students in reflecting was not fully optimal, considering the concentration of students had decreased, but the role of a teacher was needed so that students' attention at the end of the lesson could be focused on reflecting. 


\section{Student learning outcomes}

Completeness of student learning outcomes by conducting pre-test and post-test. In the pre-test there are still students who have not achieved the completeness score. After carrying out the post test, in the Obedience to the Rules material test, it has been seen that the students' completeness results have not been completed . Furthermore, the material for Competence in goodness and work ethic of student learning outcomes has reached the value of completeness.

Based on the description above, both from the activities of teachers and students as well as learning outcomes, the use of audio-visual learning media for Islamic Religious Education in Senior High Schools is basically still needed. Given the limited time in addition to a lot of learning materials need to be completed. The role of a teacher is needed in the learning process. Teachers have limited ability in the delivery of the material, is expected to aid the learning media of all constraints and shortage of teachers can be resolved and overall delivery of material delivered to the common student.

\section{CONCLUSION}

The need for Islamic education learning media is very much needed, considering that time was very limited while the material was very broad in discussion. The design of instructional media uses systematic steps in accordance with the development procedure, which begins with a preliminary study, including needs analysis, the learning design stage, the development stage through expert validation, then limited trials to students and revisions. Learning media that developed valid and practical based results observation such us, which have been put forward looks on the results of the trial, generally active students, then the learning aspect carried out by the teacher, the students' views of the learning media were in the good category, so that the influence of the use of learning media was dominant. The effectiveness of audiovisual learning media for Islamic religious education in high school by looking at the assessment of student activities, namely, 1) paying attention to the teacher's explanation, 2) paying attention to the material on the media, 3) providing questions as feedback, on the use of media, 4) using good learning media, 5) discussing the media, 6) behavior that was not relevant to student activities. In general, the results of student activity data analysis show that all activities at each meeting was in the range of tolerance limits, thus it can be said that student activity has been achieved as expected . The teacher's response after using learning media includes: 1) attractiveness aspects, 2) color aspects, 3) sound aspects and 4) image aspects. The results of the analysis of the teacher's response after doing the learning obtained an average value of $4.57(89 \%)$ in the very good category. The student's response to the learning media can be seen from various aspects, the average giving a positive response is above $50 \%$, then the audio-visual learning media of Islamic religious education meets the effective criteria.

\section{REFERENCES}

1. Yaumi M. Media \& Teknologi Pembelajaran. Jakarta: Prenadamedia Group; 2018.

2. Arsyad A. Kreatif Mengembangkan Media Pembelajaran. Jambi: Gaung Persada Press; 2017.

3. Hamalik O. Proses Belajar Mengajar. Jakarta: Bumi Aksara; 2004.

4. Muhaimin, Ghofir A, Rahman N. Strategi belajar mengajar: penerapannya dalam pembelajaran pendidikan agama. Surabaya: Citra Media; 1996.

5. Tafsir A. Ilmu Pendidikan Islam dalam Perspektif Islam. 9th Ed. Bandung: Rosdakarya; 2010.

6. Abdullah AR. Aktualisasi konsep dasar pendidikan Islam : rekonstruksi pemikiran dalam tinjauan filsafat pendidikan Islam. Yogyakarta: UII Press; 2002.

7. Darajat Z. Ilmu Pendidikan Islam. 10th Ed. Jakarta: Bumi Aksara; 2012.

8. Damopolii M. Pesantren Modern IMMIM Pencetak Muslim Modern. Jakarta: Raja Grafindo Persada; 2011.

9. Al-Abrasyi MohA. Dasar-dasar pokok pendidikan Islam. Jakarta: Bulan Bintang; 1970.

10. Rusman, Kurniawan D, Riyana C. Pembelajaran berbasis teknologi informasi dan komunikasi : mengembangkan profesionalitas guru. 1st Ed. Jakarta: Rajawali Pers; 2012.

11. Goldie JGS. Connectivism: A knowledge learning theory for the digital age? Medical Teacher. 2016 Oct 2;38(10):1064-9.

12. Dufrene RL, Tanner Z. Multimedia Compact Disc: Play Therapy Counseling Skills. Journal of Technology in Human Services. 2009 Apr 23;27(2):141-9.

13. Sanjaya W. Perencanaan dan desain sistem pembelajaran. Jakarta: Kencana; 2008.

14. Basyiruddin UM, Asnawir. Media Pembelajaran. Jakarta: Ciputat Pers; 2002.

15. Mukhtar. Desain Pembelajaran Pendidikan Agama Islam. Jakarta: Misaka Galiza; 2003.

16. Nata A. PERSPEKTIF ISLAM TENTANG STRATEGI PEMBELAJARAN. 3rd Ed. Jakarta: Kencana; 2014.

17. Thiagarajan S, Semmel DS, Semmel MI. Instructional Development for Training Teachers of Exceptional Children. University of Minnesota: Leadership training institute/special education; 1974. 